\title{
PENERAPAN MODEL PEMBELAJARAN KOOPERATIF TIPE JIGSAW UNTUK MENINGKATKAN HASIL BELAJAR SISWA MATERI ALAT PENCERNAAN MAKANAN DAN KESEHATAN BAGI MANUSIA DI KELAS V SD NEGERI 1 TAMBEA
}

\author{
Nyoman Yuni ${ }^{1)}$, Dorce Banne Pabunga ${ }^{1)}$, La Ode Kaimuddin ${ }^{1)}$, \\ ${ }^{1)}$ Jurusan Pendidikan Guru Sekolah Dasar \\ FKIP Universitas Halu Oleo \\ email:nyomanyuni.pji@gmail.com
}

\begin{abstract}
Abstrak: Rumusan masalah dalam penelitian ini adalah "Apakah penerapan model Pembelajaran Kooperatif Tipe Jigsaw dapat meningkatkan hasil belajar siswa pada materi alat pencernaan makanan dan kesehatan di kelas V SD Negeri 1 Tambea Kabupaten Kolaka?". Penelitian ini berfokus pada perbaikan proses pembelajaran sehingga meningkatkan hasil belajar IPA siswa pada materi alat pencernaan makanan dan kesehatan. Secara umum penelitian ini bertujuan untuk meningkatkan hasil belajar siswa pada materi alat pencernaan makanan dan kesehatan di kelas V SD Negeri 1 Tambea Kabupaten Kolaka melalui penerapan model Pembelajaran Kooperatif Tipe Jigsaw. Jenis penelitian ini adalah penelitian tindakan kelas, terdiri dari dua siklus yang setiap siklusnya terdiri dari dua kali pertemuan. Prosedur penelitian ini meliputi: perencanaan, pelaksanaan tindakan, observasi dan evaluasi, dan refleksi. Teknik pengumpulan data dalam penelitian ini menggunakan lembar observasi, dan evaluasi tes siklus. Teknik analisis data dalam penelitian ini menggunakan analisis deskriptif yaitu menghitung persentase aktivitas guru, aktivitas siswa dan ketuntasan hasil belajar siswa selama proses pembelajaran. Indikator keberhasilan dalam penelitian ini terdiri dua yaitu dari segi proses dan hasil belajar. Dilihat dari segi proses, tindakan dikatakan berhasil apabila minimal $90 \%$ proses pelaksanaan pembelajaran terlaksana dengan baik. Dilihat dari segi hasil, tindakan dikatakan berhasil apabila minimal $80 \%$ dari jumlah siswa mencapai nilai $\geq 60$. Berdasarkan hasil analisis dan pembahasan, menunjukkan bahwa Penggunaan model pembelajaran kooperatif tipe Jigsaw dapat meningkatkan hasil belajar IPA pada siswa kelas V SD Negeri 1 Tambea Kabupaten Kolaka materi pokok alat pencernaan makanan dan kesehatan. Hasil belajar siswa setelah menerapkan model pembelajaran kooperatif tipe Jigsaw pada siklus I sebesar 57,89\% siswa yang tuntas belajar dan pada siklus II meningkat menjadi $84,21 \%$ siswa yang tuntas belajar. Penerapan model pembelajaran kooperatif tipe Jigsaw lebih menumbuhkan minat dan motivasi siswa untuk belajar sehingga siswa lebih aktif dalam pembelajaran dan pada akhirnya meningkatkan hasil belajar siswa.
\end{abstract}

Kata kunci: Model pembelajaran, jigsaw, hasil belajar

Abstract: The formulation of the problem in this study is "Is the application of the Jigsaw Cooperative Learning model can improve student learning outcomes in food digestive and health material in class V SD Negeri 1 Tambea Kolaka Regency?". This research focuses on improving the learning process so as to improve students' science learning outcomes on the material digestion tools for food and health. In general, this study aims to improve student learning outcomes in the material food digestion and health tools in class V SD Negeri 1 Tambea Kolaka Regency through the application of the Jigsaw Type Cooperative Learning model. This type of research is classroom action research, consisting of two cycles, each cycle consisting of two meetings. The procedures of this research include: planning, implementing actions, observing and evaluating, and reflecting. Data collection techniques in this study used observation sheets, and evaluation of cycle tests. Data analysis techniques in this study used descriptive analysis, which was to calculate the percentage of teacher activity, student activity and completeness of student learning outcomes during the learning process. Indicators of success in this study consisted of two, namely in terms of the process and learning outcomes. In 
terms of the process, the action is said to be successful if at least $90 \%$ of the learning implementation process is carried out well. In terms of results, the action is said to be successful if a minimum of $80 \%$ of the number of students reaches a value of $\geq 60$. Based on the results of the analysis and discussion, shows that the use of Jigsaw type cooperative learning models can improve science learning outcomes in fifth grade students of SD Negeri 1 Tambea, Kolaka Regency food and health digestive staples. Student learning outcomes after applying the Jigsaw type of cooperative learning model in the first cycle amounted to $57.89 \%$ of students who had finished learning and in the second cycle increased to $84.21 \%$ of students who had finished learning. The application of Jigsaw type cooperative learning models fosters students' interest and motivation to learn so that students are more active in learning and ultimately improve student learning outcomes.

\section{Keywords: Learning model, jigsaw, learning outcomes}

\section{Pendahuluan}

Guru sebagai tenaga pendidik mempunyai tujuan utama dalam kegiatan pembelajaran di sekolah yaitu menciptakan suasana belajar yang aktif, inovatif, kreatif, efektif dan menyenangkan. Dengan demikian dapat memotivasi siswa untuk senantiasa aktif bertanya dan mengemukakan ide dengan baik dan bersemangat sehingga berdampak pada pencapaian hasil belajar yang optimal (Mas'ud, 2009). Pelajaran IPA pada hakekatnya adalah pelajaran yang sangat erat hubungannya dengan kehidupan yang terjadi di lingkungan sekitar. Untuk menarik minat dan perhatian siswa terhadap pelajaran IPA, guru dituntut agar menerapkan metode pengajaran yang bervariasi, tidak monoton. Salah satu metode yang dapat digunakan untuk menarik minat siswa terhadap pelajaran IPA dan mengajak siswa berperan aktif dalam pembelajaran yaitu dengan penerapan model pembelajaran kooperatif. Model pembelajaran kooperatif menuntut siswa untuk belajar dalam kelompok-kelompok kecil yang memiliki tingkat kemampuan yang berbeda. Dalam menyelesaikan tugas kelompok setiap anggota saling bekerja sama dan membantu untuk memahami suatu bahan pembelajaran. Belajar belum selesai jika salah satu teman dalam kelompok belum menguasai bahan pembelajaran menuntut setiap siswa untuk bertanggung jawab tentang ketuntasan materi pembelajaran yang harus dipelajari dan dapat menyampaikan materi tersebut kepada anggota kelompoknya.

Hasil refleksi awal di SD Negeri 1 Tambea Kabupaten Kolaka yang berjumlah 21 orang siswa menunjukkan bahwa pembelajaran IPA khususnya pada materi Alat Pencernaan Makanan dan Kesehatan Bagi Manusia masih menggunakan model pembelajaran konvensional dengan metode ceramah sehingga rata-rata hasil belajar tahun pelajaran 2015/2016 siswa kelas V adalah 5,90. Nilai ini masih tergolong rendah dari standar ketuntasan belajar yang dipersyaratkan kurikulum yakni minimal $75 \%$ siswa memperoleh nilai $\geq 60$ (Kriteria yang ditetapkan oleh sekolah) Hal itu diduga menjadi salah satu penyebab karena siswa belum terlalu aktif dalam proses belajar mengajar. Guru cenderung lebih mendominasi aktivitas pembelajaran dibanding siswa. Keadaan itulah yang menjadi salah satu sebab rendahnya hasil belajar IPA khususnya pada materi Alat Pencernaan Makanan dan Kesehatan Bagi Manusia siswa kelas V SD Negeri 1 Tambea Kabupaten Kolaka.

Berdasarkan permasalahan yang ada peneliti melakukan tindakan alternatif dalam rangka mengatasi masalah rendahnya hasil belajar siswa dengan menerapkan model pembelajaran lain yang lebih mengutamakan keaktifan siswa dan memberi kesempatan kepada siswa untuk mengembangkan potensinya secara maksimal. Model pembelajaran tersebut adalah model pembelajaran kooperatif tipe Jigsaw.

Model pembelajaran kooperatif tipe Jigsaw menempatkan siswa ke dalam tim/kelompok belajar kooperatif yang heterogen dan terdiri atas dua bagian yaitu kelompok asal dan kelompok ahli. Penentuan jumlah anggota kelompok asal didasarkan atas jumlah permasalahan yang akan dihadapi sehingga nantinya setiap anggota kelompok asal akan membahas satu permasalahan dan bersatu membentuk kelompok ahli. Setelah kelompok-kelompok ahli tersebut selesai membahas permasalahannya, mereka kembali ke kelompok asalnya untuk menjelaskan hasil 
kerjanya ke teman-teman kelompoknya. Sehingga anggota tim kelompok asal tersebut dapat menguasai materi pembelajaran.

Berdasarkan keunggulan model pembelajaran kooperatif tipe Jigsaw diyakinkan bahwa hasil belajar tersebut masih dapat ditingkatkan, sehingga dilakukan penelitian tentang Penerapan Model Pembelajaran Kooperatif Tipe Jigsaw Dalam Meningkatkan Hasil Belajar Siswa Pada Materi Alat Pencernaan Makanan dan Kesehatan Bagi Manusia di Kelas V SD Negeri 1 Tambea Kabupaten Kolaka.

Penelitian yang relevan dengan penelitian ini pernah dilakukan oleh Yuli Imron Fauzi (2008) dalam penelitiannya berjudul Model Pembelajaran Kooperatif Jigsaw Untuk Meningkatkan Aktivitas dan Hasil Belajar Mata Pelajaran Sains Kelas IV MIMA Mifathul Huda Puger-Jember yang menyimpulkan hasil belajar sains kelas IV MIMA Mifathul Huda Puger meningkatt dengan penerapan model pembelajaran kooperatif tipe Jigsaw yang ditunjukkan dengan hasil tes pada siklus II memperoleh > 70 sebanyak 25 siswa (97\%).

Masalah dalam penelitian ini adalah "Apakah penerapan model Pembelajaran Kooperatif Tipe Jigsaw dapat meningkatkan hasil belajar siswa pada materi alat pencernaan makanan dan kesehatan di kelas V SD Negeri 1 Tambea Kabupaten Kolaka?". Secara umum penelitian ini bertujuan untuk meningkatkan hasil belajar siswa pada materi alat pencernaan makanan dan kesehatan di kelas V SD Negeri 1 Tambea Kabupaten Kolaka melalui penerapan model Pembelajaran Kooperatif Tipe Jigsaw.

\section{Metode Penelitian}

Penelitian ini termasuk dalam jenis penelitian tidakan kelas. Karateristik yang khas dari penelitian tindakan kelas yakni adanya tindakan-tindakan (aksi) tertentu untuk memperbaiki proses belajar mengajar di kelas. Dalam penelitian tindakan kelas ini penelitian merencakan dua siklus dan tiap siklus terdiri dari dua kali pertemuan. Penelitian tindakan kelas ini telah dilaksanakan pada kelas V semester ganjil Tahun Pelajaran 2016/2017 pada SD Negeri 1 Tambea Kabupaten Kolaka. Subyek dalam penelitian ini adalah guru kelas V SDN 1 Tambea dan siswa kelas V SDN 1 Tambea yang berjumlah 19 orang, terdiri dari 12 orang siswa perempuan dan 7 orang siswa laki-laki.

Faktor yang diteliti dalam penelitian ini adalah :

1. Faktor siswa : Aktivitas siswa selama proses pembelajaran dan hasil belajar siswa materi pokok Alat Pencernaan Makanan dan Kesehatan Bagi Manusia melalui pembelajaran kooperatif tipe Jigsaw.

2. Faktor guru : cara guru dalam merencanakan pembelajaran IPA sesuai dengan tujuan yang telah ditetapkan dan aktivitas guru selama proses pembelajaran.

Penelitian tindakan kelas ini terdiri dari 2 (dua) siklus. Tiap siklus dua kali pertemuan dan dilaksanakan berdasarkan langkah-langkah penelitian tindakan kelas yang secara rinci dijabarkan sebagai berikut: 1) perencanaan, 2) pelaksanaan tindakan, 3) Observasi dan evaluasi dan 4) refleksi. Sumber data dalam penelitian ini adalah personil penelitian yang terdiri dari siswa dan guru (peneliti). Jenis data yang di dapatkan adalah data kuantitatif dan data kualitatif yang terdiri dari lembar observasi dan hasil tes hasil belajar .

Data yang diperoleh dalam penelitian ini dianalisis dengan menggunakan analisis deskriptif yang dimaksudkan untuk memberikan gambaran distribusi hasil belajar siswa yang diajar dengan menggunakan model pembelajaran kooperatif tipe Jigsaw.

1. Menghitung tingkat pencapaian ketuntasan belajar :

$$
\text { Secara individual \% TB }=\frac{\text { Nilai yang di capai }}{\text { Nilai Ideal }} \times 100 \%
$$


2. Menentukan persentase ketuntasan :

$$
\% \mathrm{~TB}=\frac{\Sigma \mathrm{TB}}{\mathrm{n}} \times 100 \%
$$

Keterangan :

$\sum \mathrm{TB}=$ Jumlah siswa tuntas belajar

$\mathrm{n} \quad=$ Jumlah siswa secara keseluruhan (Usman, $2001: 139$ )

Kriteria taraf keberhasilan tindakan ditentukan sebagai berikut.

$$
\begin{array}{ll}
90 \% \leq \bar{X} \leq 100 \% & : \text { Sangat Baik } \\
80 \% \leq \bar{X}<90 \% & : \text { Baik } \\
70 \% \leq \bar{X}<80 \% & : \text { Cukup } \\
60 \% \leq \bar{X}<70 \% & : \text { Kurang } \\
0 \% \leq \bar{X}<60 \% & \text { : Sangat Kurang }
\end{array}
$$

Indikator keberhasilan tindakan pembelajaran yang mencakup aspek kognitif apabila minimal $80 \%$ dari keseluruhan siswa memperoleh skor $\geq 60$. Aspek ketuntasan kinerja guru apabila $80 \%$ telah melaksanakan model pembelajaran kooperatif tipe Jigsaw.

\section{Hasil Penelitian}

Data yang diperoleh dari hasil penelitian pada setiap silklus berupa aktivitas siswa selama kegiatan pembelajaran dan pencapaian hasil ketuntasan belajar siswa. Data-data tersebut dianalisis dengan menggunakan statistik deskriptif berupa rerata, persentase ketuntasan belajar yang dimaksudkan untuk menggambarkan hasil belajar siswa yang diajar dengan menerapkan model pembelajaran kooperatif tipe Jigsaw pada materi alat pencernaan makanan dan kesehatan.

\section{Pengamatan Aktivitas Siswa}

Aktivitas siswa selama kegiatan pembelajaran diamati oleh pengamat dengan menggunakan instrumen lembar observasi aktivitas siswa. Hasil pengamatan aktivitas siswa selama kegiatan pembelajaran dideskripsikan dalam bentuk persentase, jumlah dan rerata secara keseluruhan. Hasil analisis pengamatan aktivitas siswa pada siklus I menunjukkan skor rata-rata dan persentase tiap komponen aktivitas siswa dalam kegiatan pembelajaran pada siklus I menunjukan skor yang beragam. Skor rata-rata aktivitas siswa berkisar antara 1,5 sampai 3,5 dengan rata-rata persentase sebesar 59.82\%. Hasil ini menunjukan bahwa aktivitas siswa dikategorikan kurang dalam proses belajar mengajar sehingga dianggap perlu dilanjutkan siklus II.

Berdasarkan refleksi antara peneliti dan guru bidang studi maka hal-hal yang dianggap kurang seperti mendengarkan/memperhatikan penjelasan guru, memperhatikan dan menganalisis gambar pada charta/media pembelajaran, berdiskusi dan bertanya antara siswa dan guru akan diperbaiki pada siklus II.

Pada Siklus II pengamatan aktivitas siswa selama kegiatan pembelajaran dilaksanakan oleh pengamat dengan menggunakan instrumen lembar observasi siswa selama kegiatan pembelajaran. Hasil pengamatan aktivitas siswa selama kegiatan pembelajaan dideskripsikan dalam bentuk persentase keaktifan siswa dan rerata keseluruhan. Skor aktivitas siswa selama pembelajaran pada siklus II menunjukan skor yang berbeda dari siklus I. Rerata skor aktivitas siswa menunjukan kisaran 2,50 sampai 3,75 dengan rerata persentase skor sebesar 84,82\%. Hal ini menunjukan pada siklus II terjadi peningkatan aktivitas siswa karena siswa dapat mengeksplor pengetahuan awal sehingga lebih giat dalam melakukan diskusi dan bekerja kelompok, siswa sudah mendengarkan/memperhatikan penjelasan guru, serta siswa mengalami peningkatan dalam memperhatikan dan menganalisis gambar pada charta/media pembelajaran. 


\section{Pengamatan Aktivitas Guru}

Aktivitas guru selama pembelajaran berlangsung diamati oleh 1 orang pengamat dengan menggunakan lembar pengamatan aktivitas guru. Pada siklus I, aktivitas yang diamati pada guru menyangkut membuka pelajaran, kegiatan inti, dan menutup pelajaran. Rerata skor aktivitas guru pada pelaksanaan pembelajaran siklus I berkisar antara 2,5 sampai 4 dengan persentase sebesar 76,25\%. Berdasarkan hasil ini menunjukan bahwa aktivitas guru dikategorikan cukup, namun masih ada hal-hal yang harus diperbaiki seperti dalam memotivasi siswa untuk mengikuti pelajaran, meminta kepada setiap kelompok untuk mengkaji literatur, membimbing siswa dalam mengerjakan LKS, memberikan pertanyaan-pertanyaan berdasarkan tujuan yang akan dicapai.

Aktivitas guru selama kegiatan pembelajaran berlangsung diamati oleh pengamat dengan menggunakan lembar pengamatan aktivitas guru. Pada silkus II aktivitas yang diamati pada guru menyangkut kegiatan pendahuluan, kegiatan inti dan menutup pelajaran. aktivitas guru pada proses pembelajaran menunjukan kisaran 3 sampai 4 dengan persentase sebesar 88,75\%. Hal Ini menunjukan aktivitas guru sudah menunjukan pengajaran yang sesuai, tapi masih ada yang kurang sistematis.

\section{Hasil Belajar Siswa}

Untuk mengetahui sejauh mana hasil belajar siswa selama kegiatan pembelajaran, maka guru melaksanakan penilaian pada akhir siklus I dengan menggunakan tes tertulis dalam bentuk pilihan ganda. Hasil analisis ketuntasan belajar siswa pada penilaian tes siklus I, dapat dilihat pada Tabel 4.3 berikut:

Tabel 1. Analisis Ketuntasan Hasil Belajar Siswa pada Siklus I

\begin{tabular}{|c|l|c|c|}
\hline No & \multicolumn{1}{|c|}{ Hasil Belajar } & Jumlah siswa & Persentase (\%) \\
\hline 1 & Tuntas & 11 & 57,89 \\
\hline 2 & Tidak tuntas & 8 & 42,11 \\
\hline
\end{tabular}

(Sumber: Data penelitian diolah).

Berdasarkan analisis data hasil penilaian tes pada siklus I nampak bahwa siswa yang mendapat nilai $\geq 60$ atau tuntas sebanyak 11 orang atau sebesar $57,89 \%$ dan siswa yang mendapat nilai $<60$ atau tidak tuntas sebanyak 8 orang atau sebesar $42,11 \%$. Ini menunjukan indikator keberhasilan pada siklus I sebesar $75 \%$ siswa tuntas belajar belum tercapai. Untuk mengetahui sejauhmana hasil belajar siswa selama kegiatan pembelajaran, maka guru melaksanakan penilaian pada akhir siklus II dengan menggunakan tes tertulis bentuk pilihan ganda.

Hasil ketercapaian tujuan pembelajaran pada penilaian formatif siklus II dengan rencana pembelajaran (RPP ke-2), dapat dilihat pada Tabel 2 berikut:

Tabel 2. Analisis Ketuntasan Hasil Belajar Siswa pada Siklus II

\begin{tabular}{|c|l|c|c|}
\hline No & \multicolumn{1}{|c|}{ Hasil Belajar } & Jumlah siswa & Persentase (\%) \\
\hline 1 & Tuntas & 16 & 84,21 \\
\hline 2 & Tidak tuntas & 3 & 15,79 \\
\hline
\end{tabular}

Berdasarkan analisis data dari hasil tes siklus II terlihat bahwa siswa yang mendapat nilai $\geq$ 60 atau tuntas sebanyak 16 orang atau sebesar 84,21\% dan yang mendapat nilai $<60$ atau tidak tuntas sebanyak 3 orang atau sebesar $15,79 \%$. Ini menunjukan indikator keberhasilan siklus II sebesar $75 \%$ sudah tercapai. 


\section{Pembahasan}

Penelitian ini terdiri dari dua siklus. Tiap siklus diteliti disesuaikan dengan perubahan yang dicapai serta tergantung dari materi yang dibahas. Penelitian ini dilakukan untuk peningkatan hasil belajar IPA siswa kelas V SD Negeri 1 Tambea pada materi Alat Pencernaan Makanan dan Kesehatan melalui penerapan model pembelajaran kooperatif tipe Jigsaw.

Berdasarkan hasil observasi terhadap aktivitas siswa selama proses pembelajaran mulai dari siklus I hingga siklus II yang dapat dilihat pada tabel 2 dan tabel 5, menunjukan persentase aktivitas siswa beragam dan cenderung mengalami peningkatan. Peningkatan aktivitas tersebut menunjukan adanya minat dan motivasi siswa dalam mengikuti pembelajaran dengan model pembelajaran kooperatif tipe Jigsaw. Aktivitas siswa pada siklus I, menunjukan persentase aktivitas siswa beragam namun masih kurang baik. Salah satu faktor yang menyebabkan aktivitas siswa kurang baik, karena siswa belum memahami dan terbiasa dengan model pembelajaran yang diterapkan.

Disamping itu pula, adanya faktor lain seperti aktivitas guru dalam pembelajaran sebagian masih kurang tepat dalam menerapkan model pembelajaran kooperatif tipe Jigsaw. Dimana masih terdapat aktivitas guru dalam pembelajaran yang masih kurang seperti dalam memotivasi siswa untuk mengikuti pelajaran, membimbing siswa pada saat melakukan diskusi. Selain itu ditemukan aktivitas guru yang kurang memberi penguatan dan penghargaan kepada siswa yang memberikan pertanyaan/menaggapi pertanyaan dan kelompok yang kinerjanya bagus, sehingga berpengaruh terhadap aktivitas dan hasil belajar siswa. Hal ini sejalan dengan yang dikemukakan oleh Sanjaya $(2006 ; 148)$ bahwa guru dalam pembelajaran berperan sebagai fasilitator yaitu untuk memudahkan siswa dalam kegiatan pembelajaran. Guru berperan pula sebagai pengelola yaitu menciptakan iklim belajar yang memungkinkan siswa dapat belajar dengan nyaman.

Berdasarkan hasil observasi yang dilakukan pada siklus I, menunjukan bahwa siswa yang memperoleh nilai $\geq 60$ sebanyak 11 orang atau sebesar $57,89 \%$. Sedangkan siswa yang memperoleh nilai < 60 sebanyak 8 orang atau sebesar $42,11 \%$. Ini menunjukan indikator keberhasilan siklus I sebesar $75 \%$ belum tercapai, sehingga perlu dilakukan perbaikanperbaikan utamanya kinerja guru dalam menumbuhkan minat dan motivasi belajar siswa serta dalam membimbing siswa. Selain itu ketidaktuntasan beberapa siswa tersebut diakibatkan kurangnya perhatian siswa dalam mengikuti pelajaran serta kurangnya fasilitas pembelajaran (buku) yang tersedia. Hal ini sejalan dengan pendapat yang dikemukakan oleh Slameto (2003:32) bahwa dalam usaha mencapai tujuan belajar perlu diciptakan kondisi belajar yang kondusif agar terjadi proses belajar yang optimal dan hasil belajar yang memuaskan.

Untuk mengatasi hal-hal yang masih kurang pada siklus I, dilakukan analisis dan refleksi terhadap faktor-faktor yang menyebabkan rendahnya aktivitas siswa, aktivitas guru dan hasil belajar siswa yang masih kurang dalam pembelajaran.

Berdasarkan hasil refleksi maka kelemahan/kekurangan yang ditemui pada siklus I dilakukan perbaikan pada siklus II, dimana dengan perbaikan tersebut, aktivitas siswa pada siklus II sudah mengalami banyak peningkatan seperti mendengarkan/memperhatikan penjelasan guru, memperhatikan dan menganalisis gambar pada charta/media pembelajaran, berdiskusi dan bertanya antara siswa dan guru akan diperbaiki pada siklus II.

Berdasarkan hasil observasi pada siklus II, guru dan siswa telah melakukan kegiatan pembelajaran sesuai dengan yang diharapkan, kekurangan-kekurangan pada siklus I sudah diperbaiki. Aktivitas guru sudah baik dalam menerapkan model pembelajaran kooperatif tipe Jigsaw pada materi pokok alat pencernaan makanan dan kesehatan, guru sudah mampu mengorganisasi waktu dengan baik sehingga penggunaan waktu sudah sesuai dengan yang telah ditetapkan. Guru sudah mampu mengefektifkan pemantauan dan bimbingan terhadap siswa, disamping itu siswa sudah terlihat aktif dalam mengikuti pembelajaran.

Adanya peningkatan aktivitas siswa yang signifikan dari siklus I sampai siklus II yaitu dari $49,11 \%$ pada pertemuan pertama siklus I menjadi $93,75 \%$ pada siklus II pertemuan kedua, menunjukan bahwa siswa telah memahami model pembelajaran kooperatif tipe Jigsaw, adanya minat dan motivasi belajar siswa yang tinggi dalam mengikuti pembelajaran dan siswa sudah 
mampu bersosialisasi dengan baik bahkan sebagian besar siswa sudah berani mengeluarkan pendapat dan menanggapi pertanyaan yang diberikan.

Meskipun masih ada 3 orang $(15,79 \%)$ siswa yang hingga pelaksanaan tes tindakan siklus II berakhir masih memiliki hasil belajar < 60, akan tetapi mereka sudah memberikan penghargaan dan sikap yang positif pada saat model pembelajaran kooperatif tipe Jigsaw diterapkan.

Berdasarkan hasil evaluasi yang dilakukan pada siklus II, siswa yang memperoleh nilai $\geq$ 60 sebanyak 16 orang atau sebesar 84,21\% sedangkan siswa yang memperoleh nilai < 60 sebanyak 3 orang atau sebesar $15,79 \%$. Hal ini menunjukkan indikator keberhasilan siklus II sebesar $75 \%$ telah tercapai sehingga penelitian dihentikan. Terjadi peningkatan dari hasil tes tindakan siklus I ke hasil tes tindakan siklus II yaitu siswa yang memperoleh nilai $\geq 60$ meningkat $26,34 \%$ atau bertambah 8 orang dari hasil tes tindakan siklus I.

Dari hasil evaluasi tersebut menunjukan bahwa usaha dan keberhasilan belajar dipengaruhi oleh berbagai faktor. Hal ini sesuai dengan yang dikemukakan oleh Syah (2007:132) bahwa hasil belajar dipengaruhi oleh beberapa faktor yaitu, faktor internal adalah faktor yang berasal dari diri siswa, faktor eksternal adalah faktor yang berasal dari luar diri siswa dan faktor pendekatan belajar yaitu jenis upaya belajar yang meliputi strategi dan metode yang digunakan untuk melakukan pembelajaran.

Karena indikator keberhasilan dalam penelitian ini telah tercapai dalam hal ini aktivitas belajar siswa selama proses pembelajaran sudah cukup baik dan minimal $75 \%$ siswa telah memperoleh nilai $\geq 60$. Maka, hipotesis tindakan dalam penelitian ini telah tercapai yaitu Penerapan model pembelajaran kooperatif tipe Jigsaw dapat meningkatkan hasil belajar siswa materi alat pencernaan makanan dan kesehatan di Kelas V SD Negeri 1 Tambea.

Menurut (Syah, 2007: 23) pendekatan pembelajaran Jigsaw menuntut siswa untuk melakukan Pembelajaran Aktif, Kreatif, Inovatif, Efektif, dan Menyenangkan (PAIKEM ), menyelesaikan masalah nyata sehingga siswa dapat menyusun pengetahuannya sendiri, menumbuhkembangkan keterampilan berpikir tingkat tinggi, memandirikan siswa, serta meningkatkan kepercayaan dirinya sehingga peran guru adalah mengajukan masalah, mengajukan pertanyaan, memberikan kemudahan suasana berdialog, dan memberikan fasilitas penelitian.

Hal ini sejalan dengan yang dikemukakan oleh (Wartono, dkk., 2004:20) bahwa model pembelajaran kooperatif tipe Jigsaw ini memberikan manfaat yang sangat besar terhadap siswa, antara lain (1) memotivasi siswa untuk belajar lebih giat karena adanya motivasi dari teman kelompoknya serta menyadari akan penilaian yang akan kelanjutan; (2) menghilangkan rasa takut pada siswa untuk mengungkapkan pendapatnya dan untuk menjawab pertanyaan; dan (3) menumbuhkan kemampuan kerja sama siswa, berfikir kritis dan kemampuan membantu teman.

\section{Simpulan}

Berdasrkan hasil obsevasi dan evaluasi dari setiap siklus, maka dapat disimpulkan sebagai berikut penggunaan model pembelajaran kooperatif tipe Jigsaw dapat meningkatkan hasil belajar IPA pada siswa kelas V SD Negeri 1 Tambea materi pokok Alat Pnencernaan Makanan dan Kesehatan. Hal ini dapat dilihat dari peningkatan jumlah siswa yang mengalami ketuntasan yaitu pada siklus I sebesar 57,89\% siswa yang tuntas belajar dan pada siklus II meningkat menjadi $84,21 \%$ siswa yang tuntas belajar. Hal ini disebabkan model pembelajaran yang diterapkan lebih menumbuhkan minat dan motivasi siswa untuk belajar sehingga siswa lebih aktif dalam pembelajaran dan pada akhirnya meningkatkan hasil belajar siswa. 
Jurnal Ilmiah Pembelajaran Sekolah Dasar

Volume 1 Nomor 2 - Agustus 2019,e-ISSN 26560402

Available online at:http://ojs.uho.ac.id/index.php/jipsd

\section{Daftar Pustaka}

Mas'ud, A. 2009. Pembelajaran PAIKEM (online). (http://mas'ud.blogspot.com. Diakses tanggal 3 Agustus 2016)

Sanjaya W., 2006. Pembelajaran dalam Implementasi Kurikulum Berbasis Kompetensi. Prenada Media Group. Jakarta.

Slameto, 2003. Proses Belajar Mengajar dalam sistem Kredit Semester. Bumi Aksara. Jakarta.

Syah, M., 2007. Psikologis Pendidikan. Remaja Rosdakarya. Bandung.

Usman M.U. 2001. Menjadi Guru Profesional. PT. Remaja Rosdakarya. Bandung.

Wartono, dkk. 2004. Materi Pelatihan Terintegrasi Sains. Jakarta: Depdiknas.

Yuli. 2009. Penerapan Model Pembelajaran Kooperatif Jigsaw Untuk Meningkatkan Motivasi dan Hasil Belajar Biologi Siswa Kelas X-A SMA Taman Madya Malang. Skripsi. Program Studi Pendidikan Biologi, Jurusan Biologi FMIPA Program Sarjana Universitas Negeri Malang. (Online) (http:// karya- ilmiah. um. ac. id/ index. php/ biologi/ article/ view/2756 Diakses tanggal 2 Agustus 2016) 